\title{
Capital Structure and Firm Performance in Australian Service Sector Firms: A Panel Data Analysis
}

\author{
Rafiuddin Ahmed ${ }^{1, *}$ (1) and Rafiqul Bhuyan ${ }^{2}$ \\ 1 Program of Accounting and Finance, James Cook University, Douglas, QLD 4814, Australia \\ 2 Department of Accounting and Finance, Alabama A\&M University, Normal, AL 35762, USA; \\ rafiqul.bhuyan@aamu.edu \\ * Correspondence: rafiuddin.ahmed@jcu.edu.au
}

Received: 19 August 2020; Accepted: 16 September 2020; Published: 18 September 2020 updates

\begin{abstract}
Using cross-sectional panel data over eleven years (2009-2019), or 1001 firm-year observations, this study examines the relationship between capital structure and firm performance of service sector firms from Australian stock market. Unlike other studies, in this study directional causalities of all performance measures were used to identify the cause of firm performance. The study finds that long-term debt dominates debt choices of Australian service sector companies. Although the finding is to some extent similar to trends in debt financed operations observed in companies in developed and developing countries, the finding is unexpected because the sectoral and institutional borrowing rules and regulations in Australia are different from those in other parts of the world.
\end{abstract}

Keywords: firm performance; causality tests; leverage; long-term debt; capital structure

\section{Introduction}

Capital structure is one of the most perplexing puzzles in the financial literature that deals with solutions to optimal mix of debt and equity. The seminal work of Modigliani and Miller (1958) initiated this body of work, other researchers later developed theories along the MM, and empirical researchers validated the assumptions underlying the theoretical body of the literature by examining different dimensions such as firm characteristics, time or industry sector category. A mirror image of capital structure choice is essentially a decision to fund capital from the cheapest sources to maximize income after taxes (Yazdanfar 2012). The seminal work of Jensen and Meckling (1976) posits managerial behavior in the best interest of the shareholders which is to borrow at a level that will maximize shareholder value and firm profitability. Since the work of Jensen and Meckling (1976) several researchers have examined the relationship between leverage and profitability. The findings of these studies are contradictory and mixed, some suggesting a positive relationship (Ghosh et al. 2000; Hadlock and James 2002; Roden and Lewellen 1995; Taub 1975) and some suggesting a negative relationship (Fama and French 1998; Gleason et al. 2000) between leverage and profitability (El-Sayed Ebaid 2009). There are many studies on capital structure in the context of service sectors in Europe, USA, the Middle East and other parts of the world (Chakrabarti and Chakrabarti 2019; Choi et al. 2018; Park and Jang 2018; Sardo et al. 2020; Sermpinis et al. 2019; Szemán 2017). Compared to other sectors, service sector capital structure research is at a nascent stage. Further research needs to be done to enrich the understanding of the drivers of financial performance of this sector.

The key aim of this paper is to empirically examine the relationship between debt financing and firm performance of service sector companies listed in the Australian Stock Exchange. The service sector is chosen to reflect the changing configuration of the Australian economy from a resource-based economy to a service-based economy. Over the last one and a half decades, the Australian service sector contributed between $60-70 \%$ and is a major employer (Australian Bureau of Statistics 2019, 
2020). This trend is expected to continue in the foreseeable future and it is important to get some insights into the effect of capital structure on this sector firms. Four performance measures are used to capture firm performance: (a) return on asset, (b) return on equity, (c) return on capital employed and (d) operating margin. The paper finds: (a) portability (measured by return on equity, ROE) and leverage (measured by a ratio of short-term debt to total assets) is positively associated, (b) profitability (measured by return on assets) and leverage (measured by short-term debt) is positively associated and (c) no significant association between either ROE and ROA and long-term or total debt. The main contribution of this paper is that it has extended the current body of literature on capital structure by adding the Australian service industry context from very recent data. Australia's move from a resource-based economy to a service-based economy means the sector is growing, so the findings of this paper are expected to shed light on this emerging frontier of capital structure practices of service sector firms. The remainder of the paper is organized as follows. In Section 2, the literature is discussed. In the third section, the empirical literature is reviewed, followed by three sections on data, results and discussions. The final section concludes the paper with some possible directions for future research.

\section{Literature Review}

Numerous theories have been developed following the initial development of capital structure theory by Modigliani and Miller (1958). These theories were later classified by their assumptions about how they affect firm value in the financial market. The first of these theories is the Trade-off theory of capital structure. This theory precedes some initial refinements in 1963 (Modigliani and Miller 1963) of Modigliani and Miller's (1958) initial work, in which taxes are added to theorize the effect of taxes on a firm's tax payable amount, increase in after tax income and its market value. This development was later labelled as trade-off theory, a theory which states that a firm's optimal leverage is achieved by minimizing taxes, costs of financial distress and agency costs. Baxter (1967) argued that increased debt levels increases the chances of bankruptcy and increases interest payable to the debtholders. A firm's optimal leverage is where tax advantage from debt exactly equals the cost of debt. Kraus and Litzenberger (1973) argue that a firm's market value declines if its debt obligations are greater than its earnings. DeAngelo and Masulis (1980) propose the static trade off theory and include other tax minimizing offsets such as depreciation and investment tax credits. They argue that firms weigh tax advantages of debt against business risk (a cost). Their theoretical model proposes that a firm's optimum debt level is where the present value of tax savings from debt equals the present value of costs of distress.

Myers (1984), in his theoretical explanation of the asymmetric information hypothesis, proposes different information held by firms' internal and external stakeholders. Managers hold real information about firms' income distribution plans (Ross 1977). Thus, firm's leverage level signals its confidence levels, suggesting lower leverage as a poor signal about income and its distribution potential and vice versa. Pettit and Singer (1985) discuss the problems of asymmetric information and possible agency costs affecting firms' demand and supply of credit. They argue that small firms possess a higher level of asymmetric information due to financial constraints for sufficient disclosure of financial information to outsiders. This theory has laid the foundation for Pecking Order Theory (POT). Donaldson (1984) proposes the concepts and ideas of Pecking Order Theory (POT) which was later refined by Myers (1984) and Myers and Majluf (1984). The fundamental premise of this theory is that firms' preferences for funding is stacked by a pecking order of risk preferences and corresponding costs. Thus, firms use the cheapest source of internal funds such as retained earnings, debt, convertible debt and preference shares) and external equity (Myers 1984). The cost of sourcing extra funding is dependent on the extent of information asymmetries of risk perceptions emanating from differential information needs held by inside management and potential investors. In addition to a firm's desire to source the cheapest fund to finance its needs, other factors, such as the stage of development of a firm (a startup, a mature firm etc.) influence the supply of funds (Macan Bhaird and Lucey 2010). 
Agency theory (Jensen and Meckling 1976) addresses the fundamental problem of managing a firm's capital structure from the cheapest source of funds. While common equity is an expensive source of funds, its use results in suboptimal firm value when equity holders insist on risk reduction from lower leverage usage. If managers' and shareholders' interests are not aligned, it is highly unlikely that optimal firm value is ever going to eventuate from managerial actions. The debtholders' risk perceptions encourage them to ask for debt covenants or other costly debt shielding instruments. The tensions between the two subgroups of owners impose increased risk of monitoring by management, resulting in costly monitoring and hence, agency costs. A number of remedial measures can be implemented such as reduction in consumption of resources when debt and bankruptcy risks increase (Grossman and Hart 1982), increasing the stake of managers in a firm or increasing the leverage (Jensen 1986), commonly packed as 'free cash flow hypothesis'. Free cash flow hypothesis proposes adoption of measures to reduce free cash flow at managers' disposal by increasing leverage (Stulz 1990) so that less cash flow is available for desired investment choices.

The theories above are prevalent in different country specific studies. An empirical study by El-Sayed Ebaid (2009) on Egyptian firms suggest a negative relationship between profitability and shorter-term or total debt when return on asset is used to measure profitability. The results also suggest no significant relationship between short-term or long-term debt and profitability when return on equity or gross margin is used as a measure of profitability. Salim and Yadav's (2012) study on 237 listed Malaysian companies from 1995-2001 found a negative relationship between short-term and long-term debts and all measures of profitability, return on assets, return on equity and earnings per share. Ahmed Sheikh and Wang (2011) examined 240 listed Pakistani non-financial companies during the 2004-2009 period. Three statistical tests, fixed effects, random effects and ordinary least squares found negative relationships between debt and return on assets. Weill (2008) used the maximum likelihood estimation method to analyze the effect of financial leverage on the performance of 11,836 firms from seven European countries over a three-year time period, 1998-2000. The results indicate that the long-term debt ratio is positively related at statistically significant level in Spain and Italy but negatively related at statistically significant level in Germany, France, Belgium and Norway, and insignificantly in Portugal. Goddard et al. (2005) used the generalized methods of moments system to test the determinants of profitability of manufacturing and service firms in Belgium, France, Italy and the U.K. from 1993-2001. They found a negative relationship between the sample firms' gearing ratio and profitability, and higher profitability in more liquid firms. Abor (2007) used a generalized least squares regression to study a sample of 160 Ghanaian and 200 South African Small and Medium Enterprises (SMEs) from 1998-2003 and found a negative relationship between longer-term and total debt ratios and profitability. Yazdanfar and Öhman's (2015) study used 15,897 Swedish SMEs from five different sectors from 2009-2012 to examine the effect of three different forms of debt ratios, trade credit, short-term debt and long-term debt on profitability. The results suggest a negative relationship between all types of debts and profitability, suggesting an increased use of equity capital to finance Swedish SMEs.

There are not many Australian studies on the relationship between capital structure and profitability. $\mathrm{Li}$ and Stathis (2017) examined the determinants of the capital structure of Australian manufacturing listed traded firms. The study used eight factors: profitability, log of assets, median industry leverage, industry growth, market-to-book ratio, tangibility, capital expenditure and investment tax credits. They found weak support for the pecking order hypothesis and increasing support for the trade-off theory in Australia. Qiu and La (2010) examined the relationship between firm characteristics and capital structure of 367 Australian firms over a 15 year period. Their study identified the role of debt on profitability, tangibility, growth prospects and risk of these firms. They concluded that profitability has the potential to reduce debt levels of Australian firms, implying debt reduction through increased profits was possible in Australian firms. Barth et al. (2001) examined the relationship between capital structure and profitability of 107 countries including Australia. They tested for regulatory power, supervision, and other factors affecting the relationship between profitability and leverage across the countries studied. Rashid and Islam (2009) examined 60 companies in the Australian 
Financial services sector during the years 2002-2003. The results suggest that profitability is negatively affected by leverage, and positively affected by board size, liquid markets and information efficiency (all control variables).

Firm performance as a measure of the impact of different proxies for capital structure has added new insights in recent times. Some country-specific studies have examined the direct effect of using different types of debts on firm performance. Most of these studies reported a significant negative relationship between debts and firm performance. Chakrabarti and Chakrabarti (2019) examined firm-specific and macro-economic variables on 18 Indian non-insurance firms for seven years. They found a positive relationship between low insurance, low input costs, low inflation rates, higher return on investment, liquidity and profitability. Dalci (2018) examined the impact of capital structure on 1503 listed manufacturing firms in the Chinese stock exchange between the years 2008-2016. They found an inverted U-shaped relationship between capital structure and profitability and provided the causes of a negative and positive relationship between financial leverage (as a measure of capital structure) and profitability. This is a major study that highlighted the importance of the developments of credit market policies and rules for the advancement of different-sized Chinese manufacturing firms.

Dave et al. (2019) examined the impact of capital structure and profitability of firms in the Indian Steel industry and observed a significant negative relationship between long-term and short-term debts as a ratio of total assets and profitability. Helmy et al. (2020) examined the impact of capital structure, internal governance mechanism, and firm-performance of 183 Bursa-listed Malaysian companies for the years 2007-2010. They found a positive impact of capital structure on firm performance. Gharaibeh and Bani Khaled (2020) examined the factors that played key roles in the profitability of 46 Jordanian service sector companies between the years 2014-2018. They found that debt as a portion of total assets and tangible assets have significantly negative relationships with profitability whereas tangible size and business risk had a positive relationship with profitability.

Hussein et al. (2019) examined listed Jordanian firms between 2005-2017. Using three measures of firm performance, return on assets, Tobin's $Q$ and return on assets, and total and short-term debt as a proxy for capital structure, they observed a positively significant relationship between firm size, asset growth, significant negative relationship between short-term debt and long-term debt and return on assets. However, they did not find any significant negative relationship between short-term and long-term debts and return on equity measure of firm performance. Lastly, Yazdanfar examined 15,897 firms working in five SME sectors of the Swedish economy between 2009-2012. They found debt ratios (trade-credit, short-term and long-term debts) negatively affected firm profitability.

Capital structure studies that examined the relationship between different proxies for capital structure and firm performance used a variety of measures to define profitability. Some studies used a single measure (see, for example, Arifin 2017; Negasa 2016) while others used multiple measures such as return on Equity (ROE), return on assets (ROA), and return on capital invested (ROCE) (see, for example, Gharaibeh and Bani Khaled 2020; Musah and Kong 2019). In these studies, different types of debts are used as proxies for capital structure and different control variables are used to measure the collective impacts on firm performance. The relationship between firm performance and capital structure is assumed to be unidirectional in most of the studies reviewed above. However, some recent studies validated the causal relationship between capital structure and firm performance (Arifin 2017; M'ng et al. 2017). Finally, the studies above showed a negative, positive, and mixed relationship between capital structure measures and firm performance.

The studies are from diverse sectors and cover a wide range of firm year cross sectional observations. There is a limited number of studies that examine the linkage between different measures of firm performance (or profitability) and capital structure. Studies covering the services sector are hardly noteworthy in the Australian and global contexts. Moreover, the directional causal relationship between different types of borrowings and firm performance is hardly examined in detail in the studies 
reviewed above. This study contributes to the growing body of literature in the study of capital structure in the under-researched domains of service sector firms in Australia and internationally.

\section{Data}

We consider a comprehensive database from the Australian service sector (as classified by Australian Bureau of Statistics) for the period 2009 to 2019. The data was collected from Datanalysis database-a database that publishes financial data of companies in different Australian sectors. Although our initial sample was much larger than what we have included in the study, due to matching inconsistency in variable definition and the availability of all variables of all companies, we have truncated the data to 91 companies that have same data set for the entire time period. These companies are all listed in the Australian Stock Exchange.

Table 1 shows that a total of nine sectors are considered to conduct research for the period 2009 to 2019. Based on the availability of the entire data set with chosen variables, some sectors had the most samples and others had only a few companies. The percentage column shows the degree of weight from each sector of our sample. Based on the literature surveyed, we consider several variables shown in Table 2 to investigate our research question.

To avoid spurious regression estimates in our empirical analysis, variables under consideration should ideally be stationary. To confirm this, we used the panel unit root test of Levin et al. (2002). Table 3 shows that the unit-roots hypothesis is rejected by all variables at the $1 \%$ level of significance. Following (Canarella and Miller 2018; Köksal and Orman 2015; Khan et al. 2018; M'ng et al. 2017), we also checked for stationarity using a unit root test and observed that all variables were stationary with respect to the dependent variables (Return on Equity (ROE), Operating Margin (op_margin), Return on Asset (ROA) and Return on Invested Capital (ROIC)), confirmed by the tests for heteroscedasticity and autocorrelation diagnostics.

The panel regressions were run for four dependent variables (return on equity, return on assets, return on invested capital, and operating margin), two treatment variables (leverage and long-term debt to total assets ratio), and five control variables (size, liquidity, revenue growth for three years, tangibility and depreciation tax shield). A series of regressions were run for these variables and diagnostic tests were conducted to confirm the appropriateness of fixed or random effects panel regressions models.

For each of the dependent variables, outputs for two models are presented, after eliminating the inappropriate models using Hausman tests. The Breausch Pagan test was employed to confirm the outputs of the Hausman test for this purpose. Earlier studies in capital structure used the Hausman test to identify the appropriate panel data model from two available models: fixed effect model and random effect model (Dalci 2018; Mayuri and Kengatharan 2019; Sivalingam and Kengatharan 2018; Suntraruk and Liu 2017). Breausch Pagan Lagrange Multiplier tests were used for confirming the appropriateness of the random effects model (see for example, Dalci 2018; Ghasemi et al. 2018; Khan et al. 2018). The tables below present the outputs of these models.

Table 1. Table shows the various Australian service sector companies considered for this research.

\begin{tabular}{cccc}
\hline Sector-ID & Frequency & Percent & Cumulative Percentage \\
\hline Utilities & 242 & 24.18 & 24.18 \\
Construction & 33 & 3.30 & 27.47 \\
Retail trade & 132 & 13.19 & 40.66 \\
Transport & 143 & 14.29 & 54.95 \\
Communication services & 308 & 30.77 & 85.71 \\
Consumer discretionary & 22 & 2.20 & 87.91 \\
Commercial services & 121 & 12.09 & 100.00 \\
Total & 1001 & 100.00 & \\
\hline
\end{tabular}

(Source: Authors' compilation). 
Table 2. List of dependent and explanatory variables.

\begin{tabular}{|c|c|c|c|c|c|c|c|c|c|}
\hline \multicolumn{3}{|c|}{ Variables } & \multicolumn{3}{|c|}{ Calculated as } & \multicolumn{4}{|c|}{ Sources } \\
\hline \multicolumn{3}{|c|}{ Return on assets (ROA) } & \multicolumn{3}{|c|}{ Earnings before Interest and tax (EBIT)/Total assets } & \multicolumn{4}{|c|}{$\begin{array}{c}\text { (Dalci 2018; Gharaibeh and Bani Khaled 2020; Goddard et al. 2005; } \\
\text { Nunes et al. 2009) }\end{array}$} \\
\hline \multirow{2}{*}{\multicolumn{3}{|c|}{$\begin{array}{c}\text { Return on equity (ROE) } \\
\text { Operating margin (op margin) }\end{array}$}} & \multicolumn{3}{|c|}{ EBIT/Total Equity } & \multicolumn{4}{|c|}{ (Arifin 2017; Dalci 2018; Gharaibeh and Bani Khaled 2020) } \\
\hline & & & \multicolumn{3}{|c|}{ EBIT/Operating revenue } & \multicolumn{4}{|c|}{ (Gharaibeh and Bani Khaled 2020) } \\
\hline \multicolumn{3}{|c|}{ Return on Invested Capital (ROIC) } & \multicolumn{3}{|c|}{ EBIT/Invested capital } & \multicolumn{4}{|c|}{ (Musah and Kong 2019) } \\
\hline \multicolumn{3}{|c|}{ Leverage } & \multicolumn{3}{|c|}{ Total liabilities/total assets } & \multicolumn{4}{|c|}{ (Gharaibeh and Bani Khaled 2020; Nunes et al. 2009) } \\
\hline \multicolumn{3}{|c|}{ Long-term debt to total asset (LTd_TA) } & \multicolumn{3}{|c|}{ Long-term debt/total assets } & \multicolumn{4}{|c|}{ (Yazdanfar and Öhman 2015) } \\
\hline \multicolumn{3}{|c|}{ Liquidity } & \multicolumn{3}{|c|}{ Current assets/Current liabilities } & \multicolumn{4}{|c|}{ (Nunes et al. 2009) } \\
\hline \multicolumn{3}{|c|}{ Tangibility } & \multicolumn{3}{|c|}{ Fixed assets/Total assets } & \multicolumn{4}{|c|}{$\begin{array}{c}\text { (Fitim et al. 2019; Gharaibeh and Bani Khaled 2020; Nunes et al. 2009; } \\
\text { Shalini and Biswas 2019) }\end{array}$} \\
\hline & Tax shield & & \multicolumn{3}{|c|}{$\begin{array}{l}\text { Depreciation/Total assets } \\
\text { Log of Operating revenue }\end{array}$} & \multicolumn{4}{|c|}{ (Fitim et al. 2019; Shalini and Biswas 2019; Yazdanfar and Öhman 2015) } \\
\hline \multirow{2}{*}{\multicolumn{3}{|c|}{$\begin{array}{l}\text { Operating revenue (size) } \\
\text { Revenue growth (3-year) }\end{array}$}} & \multicolumn{3}{|c|}{ Log of Operating revenue } & \multirow{2}{*}{\multicolumn{4}{|c|}{$\begin{array}{l}\text { (Fitim et al. 2019; Shalini and Biswas 2019) } \\
\text { (Chadha and Sharma 2015; Chakrabarti and Chakrabarti 2019) }\end{array}$}} \\
\hline & & & $\%$ of revenu & rowth (3 ye & average, given) & & & & \\
\hline ROIC & ROE & ROA & OP_MARGIN & LTD_TA & LEVERAGE & TAXSHIELD & TANBIBILITY & LIQUIDITY & LNSALES \\
\hline $\begin{array}{l}-6.4783 \\
(0.0000)\end{array}$ & $\begin{array}{l}-6.04 \\
(0.0000)\end{array}$ & $\begin{array}{l}-9.75 \\
(0.0000)\end{array}$ & $\begin{array}{l}-7.0134 \\
(0.0000)\end{array}$ & $\begin{array}{l}-9.1691 \\
(0.0000)\end{array}$ & $\begin{array}{l}-3.2673 \\
(0.0000)\end{array}$ & $\begin{array}{l}-5.5693 \\
(0.0000)\end{array}$ & $\begin{array}{c}-12.2987 \\
(0.0000)\end{array}$ & $\begin{array}{l}-5.9927 \\
(0.0000)\end{array}$ & $\begin{array}{c}-11.4026 \\
(0.0000)\end{array}$ \\
\hline
\end{tabular}




\section{Results}

In the following section, we have presented the results of our analysis. Four different measures of financial performance and six explanatory variables were analyzed to identify the important explanatory variables affecting firm performance of Australian service sector firms between the years 2009 and 2019. In each table below, two models are presented: Model 1 and Model 2. In Model 1 , leverage is used as a treatment variable and in Model 2, long-term debt is used as the treatment variable. Size, depreciation tax-shield, revenue growth for 3 years, operating revenue (measure of size), liquidity and tangibility are used as control variables in measuring firm performance.

As shown in Table 4, the fixed effect model (FEM) in Model 1 identified leverage, tangibility, liquidity and operating revenue as important predictors of operating margin. The random effect model (REM) in Model 1 identified leverage, tangibility, operating revenue and revenue growth for three years as significant predictors of operating margin. The constant is also important at $1 \%$ level of significance. The Granger causality test shows a unidirectional relationship between leverage and operating margin. This relationship is positive as evidenced by a significant positive coefficient of leverage.

Table 4. Panel regression outputs for operating margin (dependent variable).

\begin{tabular}{|c|c|c|c|c|}
\hline \multirow[t]{2}{*}{ Dependent Variable } & \multicolumn{2}{|c|}{ Model 1} & \multicolumn{2}{|c|}{ Model 2} \\
\hline & FEM & REM & FEM & REM \\
\hline leverage & $\begin{array}{c}0.5972 \text { * } \\
(4.48)\end{array}$ & $\begin{array}{c}0.2411^{* *} \\
(2.23)\end{array}$ & & \\
\hline LTD_TA & & & $\begin{array}{c}-0.0447 \\
(-1.21)\end{array}$ & $\begin{array}{c}-0.0295 \\
(-0.88)\end{array}$ \\
\hline Depreciation tax shield & $\begin{array}{l}-0.0041 \\
(-0.10)\end{array}$ & $\begin{array}{c}-0.1265 \\
(-0.36)\end{array}$ & $\begin{array}{l}-0.0208 \\
(-0.49)\end{array}$ & $\begin{array}{c}-0.0179 \\
(-0.51)\end{array}$ \\
\hline Tangibility & $\begin{array}{c}-0.04682^{* *} \\
(-1.21)\end{array}$ & $\begin{array}{c}-0.0584^{* * *} \\
(-1.80)\end{array}$ & $\begin{array}{l}-0.0640 \\
(-1.63)\end{array}$ & $\begin{array}{c}-0.0648^{* *} \\
(-1.97)\end{array}$ \\
\hline Liquidity & $\begin{array}{c}0.1589 * * \\
(2.15)\end{array}$ & $\begin{array}{l}0.0191 \\
(0.32)\end{array}$ & $\begin{array}{c}-0.0983 * * * \\
(-1.69)\end{array}$ & $\begin{array}{c}-0.0893^{* * *} \\
(-1.78)\end{array}$ \\
\hline Operating revenue & $\begin{array}{c}0.0075 \text { * } \\
(2.39)\end{array}$ & $\begin{array}{l}0046 * \\
(2.84)\end{array}$ & $\begin{array}{c}0.0086 \text { * } \\
(2.68)\end{array}$ & $\begin{array}{c}0.0059 * \\
(3.68)\end{array}$ \\
\hline Revenue growth (3-year) & $\begin{array}{l}-0.0081 \\
(-2.66)\end{array}$ & $\begin{array}{c}-0.0074^{* *} \\
(-2.45)\end{array}$ & $\begin{array}{c}-0.0091 * \\
(-2.95)\end{array}$ & $\begin{array}{c}-0.0080 * \\
(-2.65)\end{array}$ \\
\hline Constant & $\begin{array}{c}0.0454 \\
(0.22)\end{array}$ & $\begin{array}{c}0.5986 \text { * } \\
(3.92)\end{array}$ & $\begin{array}{c}0.9164 \text { * } \\
(9.34)\end{array}$ & $\begin{array}{c}0.9457 * \\
(12.37)\end{array}$ \\
\hline F-test & $\begin{array}{c}6.49 \\
(0.0000)\end{array}$ & & $\begin{array}{c}3.32 \\
(0.0031)\end{array}$ & \\
\hline Hausman test & & $\begin{array}{c}24.85 \\
(0.0000)\end{array}$ & & $\begin{array}{c}3.80 \\
(0.7033)\end{array}$ \\
\hline Breusch-Pagan test & & $\begin{array}{c}445.16 \\
(0.0000)\end{array}$ & & $\begin{array}{c}480.54 \\
(0.0000)\end{array}$ \\
\hline
\end{tabular}

$*, * *$ and ${ }^{* * *}$ are used for $1 \%, 5 \%$ and $10 \%$ level of significance.

In Model 2, the fixed effect model identified liquidity, operating revenue and revenue growth as significant predictors of operating margin. In the random effects model, tangibility, liquidity and operating revenue are significant predictors of operating margin. In both models, the constants are significant at $1 \%$ level. The Granger causality test revealed a unidirectional relationship between long-term debt to total asset and operating margin. This relationship is negative but not significant at any level.

In Table 5, the random effect model of Model 1 identified leverage, operating revenue, revenue growth as significant predictors of return on assets. In the fixed effect model of Model 1, leverage, 
operating revenue and growth are significant predictors of return on assets. The Granger causality test indicates a bi-directional causality between leverage and return on asset. Leverage significantly pulls return on assets down, as evidenced by the negative coefficient in the equations in Model 1.

Table 5. Panel regression outputs for Return on Asset (ROA).

\begin{tabular}{|c|c|c|c|c|}
\hline \multirow[t]{2}{*}{ Variables } & \multicolumn{2}{|c|}{ Model 1} & \multicolumn{2}{|c|}{ Model 2} \\
\hline & REM & FEM & REM & FEM \\
\hline leverage & $\begin{array}{c}-1.1143 \text { * } \\
(-3.75)\end{array}$ & $\begin{array}{c}-1.6487^{*} \\
(-4.58)\end{array}$ & & \\
\hline LTD_TA & & & $\begin{array}{c}0.2475^{* *} \\
(2.49)\end{array}$ & $\begin{array}{c}0.1819^{* *} \\
(1.98)\end{array}$ \\
\hline Depreciation tax shield & $\begin{array}{c}0.01242 \\
(0.13)\end{array}$ & $\begin{array}{c}-0.1814 \\
(-1.60)\end{array}$ & $\begin{array}{c}-0.1288 \\
(-1.13)\end{array}$ & $\begin{array}{c}0.0429 \\
(0.44)\end{array}$ \\
\hline Tangibility & $\begin{array}{c}-0.01436 \\
(-0.16)\end{array}$ & $\begin{array}{c}0.05435 \\
(0.52)\end{array}$ & $\begin{array}{c}0.0810 \\
(0.77)\end{array}$ & $\begin{array}{c}0.0045 \\
(0.05)\end{array}$ \\
\hline Liquidity & $\begin{array}{c}0.2029 \\
(1.24)\end{array}$ & $\begin{array}{c}0.1243 \\
(0.62)\end{array}$ & $\begin{array}{c}0.9096 \text { * } \\
(5.82)\end{array}$ & $\begin{array}{c}0.7347^{*} \\
(5.35)\end{array}$ \\
\hline Operating revenue & $\begin{array}{c}0.02992 \text { * } \\
(6.61)\end{array}$ & $\begin{array}{c}0.01709 \text { ** } \\
(2.01)\end{array}$ & $\begin{array}{c}0.0120 \\
(1.39)\end{array}$ & $\begin{array}{c}0.0232 \text { * } \\
(5.19)\end{array}$ \\
\hline Revenue growth (3-year) & $\begin{array}{c}0.0168^{* *} \\
(2.06)\end{array}$ & $\begin{array}{c}0.01639 * * \\
(1.98)\end{array}$ & $\begin{array}{c}0.0193^{* *} \\
(2.32)\end{array}$ & $\begin{array}{c}0.01966^{* *} \\
(2.38)\end{array}$ \\
\hline Constant & $\begin{array}{c}0.3210 \\
(0.76)\end{array}$ & $\begin{array}{c}1.2644^{* *} \\
(2.03)\end{array}$ & $\begin{array}{c}-1.2744 \text { * } \\
(-4.82)\end{array}$ & $\begin{array}{c}-1.3402 \text { * } \\
(-6.41)\end{array}$ \\
\hline F-test & & $\begin{array}{c}10.06 \\
(0.0000)\end{array}$ & & $\begin{array}{c}7.48 \\
(0.0000)\end{array}$ \\
\hline Hausman test & $\begin{array}{c}26.13 \\
(0.0002)\end{array}$ & & $\begin{array}{c}21.04 \\
(0.0016)\end{array}$ & \\
\hline Breusch-Pagan test & $\begin{array}{c}544.07 \\
(0.0000)\end{array}$ & & $\begin{array}{c}532.38 \\
(0.0000)\end{array}$ & \\
\hline
\end{tabular}

$*, * *$ and ${ }^{* * *}$ are used for $1 \%, 5 \%$ and $10 \%$ level of significance.

The constant is also significant at the $5 \%$ level. We also observe that in both fixed effect model and random effect model of Model 2, long-term debt to total assets, liquidity, operating revenue and revenue growth for three years are significant predictors of return on assets. The constant is also significant at the $1 \%$ level.

In the Table 6, the fixed effect model in Model 1 (leverage as treatment variable), leverage, tax shield, tangibility and operating revenue are significant explanatory variables of return on capital invested. In the random effects model, leverage, tax shield, tangibility and operating revenue are significant predictors of return on invested capital. In both models, the constants are significant at the $10 \%$ level of significance. The Granger causality test indicates a bi-directional relationship between leverage and return on invested capital. This relationship is negative, as evidenced by the negative coefficient of leverage.

In Model 2 (long-term debt as a treatment variable), long-term debt, tax shield, tangibility, liquidity and operating revenue are significant predictors of return on capital employed. In the random effects model in Model 2, long-term debt, tax shield, tangibility, liquidity and operating revenue are significant predictors of return on invested capital. The constant is also significant at the $10 \%$ level. When we run the Granger's causality test, we only observe a unidirectional relationship between long-term debt to total assets and return on invested capital. That is, return on invested capital is largely influenced by debt positively. Granger causality test indicates a uni-directional relationship between long-term 
debt and return on invested capital. This relationship is positive, as evidenced by the coefficient of long-term debt above.

Table 6. Return on invested capital (RoIC).

\begin{tabular}{|c|c|c|c|c|}
\hline \multirow[t]{2}{*}{ Dependent Variable } & \multicolumn{2}{|c|}{ Model 1} & \multicolumn{2}{|c|}{ Model 2} \\
\hline & FEM & REM & FEM & REM \\
\hline Leverage & $\begin{array}{c}-7.6385^{* *} \\
(-2.17)\end{array}$ & $\begin{array}{c}-7.509 * * \\
(-2.42)\end{array}$ & & \\
\hline LTD_TA & & & $\begin{array}{c}2.1416^{* *} \\
(2.22)\end{array}$ & $\begin{array}{c}1.6844^{* * *} \\
(1.83)\end{array}$ \\
\hline Depreciation tax shield & $\begin{array}{c}-3.5081 * \\
(-3.16)\end{array}$ & $\begin{array}{c}-2.4426 \text { ** } \\
(-2.45)\end{array}$ & $\begin{array}{c}-3.2105^{*} \\
(-2.9)\end{array}$ & $\begin{array}{c}-2.2261 \text { ** } \\
(-2.23)\end{array}$ \\
\hline Tangibility & $\begin{array}{c}-2.4543^{* *} \\
(-2.40)\end{array}$ & $\begin{array}{l}-3.152 * \\
(-3.41)\end{array}$ & $\begin{array}{c}-2.4969 * * \\
(-2.43)\end{array}$ & $\begin{array}{c}-3.0967 * \\
(-3.33)\end{array}$ \\
\hline Liquidity & $\begin{array}{c}-0.4048 \\
(-0.21)\end{array}$ & $\begin{array}{c}0.09087 \\
(0.05)\end{array}$ & $\begin{array}{c}3.8359 * * \\
(2.53)\end{array}$ & $\begin{array}{c}4.0090 * \\
(2.86)\end{array}$ \\
\hline Operating revenue & $\begin{array}{c}0.2143^{* *} \\
(2.58)\end{array}$ & $\begin{array}{c}0.2100 \text { * } \\
(4.09)\end{array}$ & $\begin{array}{c}0.17597^{* *} \\
(2.09)\end{array}$ & $\begin{array}{c}0.1623 \text { * } \\
(3.15)\end{array}$ \\
\hline Revenue growth (3-year) & $\begin{array}{c}0.05104 \\
(0.63)\end{array}$ & $\begin{array}{l}0.0623 \\
(0.78) \\
\end{array}$ & $\begin{array}{c}0.06777 \\
(0.84)\end{array}$ & $\begin{array}{c}0.0803 \\
(1.00) \\
\end{array}$ \\
\hline Constant & $\begin{array}{c}8.9454^{* * *} \\
(1.66)\end{array}$ & $\begin{array}{c}8.1662^{* * *} \\
(1.83)\end{array}$ & $\begin{array}{c}-3.893121 \\
(-1.52)\end{array}$ & $\begin{array}{c}-3.6585^{* * * *} \\
(-1.70)\end{array}$ \\
\hline F-test & $\begin{array}{c}4.52 \\
(0.0000)\end{array}$ & & $\begin{array}{c}4.56 \\
(0.000) \\
\end{array}$ & \\
\hline Hausman test & & $\begin{array}{l}13.67 \\
(0.00)\end{array}$ & & $\begin{array}{c}16.76 \\
(0.0102)\end{array}$ \\
\hline Breusch-Pagan test & & $\begin{array}{c}1149.89 \\
(0.00)\end{array}$ & & $\begin{array}{c}1166.45 \\
(0.0000)\end{array}$ \\
\hline
\end{tabular}

${ }^{*}, * *$ and ${ }^{* * *}$ are used for $1 \%, 5 \%$ and $10 \%$ level of significance.

In Table 7 below, in Model 1, the random effect regression identified leverage and tangibility as two important explanatory variables of return on equity. The fixed effect model identified tangibility, size and liquidity as significant explanatory variables at the $5 \%$ level of significance. The Granger causality test indicates a unidirectional relationship between leverage and return on equity. This relationship is positive in the REM regression of Model 1 above.

In model 2 (long-term debt as a second measure of debt level), long-term debt to total assets, tangibility, liquidity and operating revenues were identified as significant explanatory variables of return on equity at the $1 \%$ level of significance. In the random effects model, long-term debt, tangibility and operating revenues were identified at the $5 \%, 1 \%$ and $10 \%$ levels of significance, respectively. The Granger causality test suggests a bi-directional relationship between long-term debt and return on equity. The positive coefficient of long-term debt to total assets in the equations in Model 2 in Table 7 indicates long-term debt to finance the purchase of assets for operations is beneficial to Australian service sector firms. 
Table 7. Panel regression output for Return on Equity (ROE).

\begin{tabular}{|c|c|c|c|c|}
\hline \multirow[t]{2}{*}{ Dependent Variable } & \multicolumn{2}{|c|}{ Model 1} & \multicolumn{2}{|c|}{ Model 2} \\
\hline & REM & FEM & FEM & REM \\
\hline Leverage & $\begin{array}{c}3.8214 \text { * } \\
(2.76)\end{array}$ & $\begin{array}{l}3.7031 \\
(1.41)\end{array}$ & & \\
\hline LTD_TA & & & $\begin{array}{c}3.3723 \text { * } \\
(4.73)\end{array}$ & $\begin{array}{c}1.2797 \text { ** } \\
(2.45)\end{array}$ \\
\hline Depreciation tax shield & $\begin{array}{c}0.1380 \\
(0.29)\end{array}$ & $\begin{array}{c}-0.9583 \\
(-1.15)\end{array}$ & $\begin{array}{c}-0.8636 \\
(-1.05)\end{array}$ & $\begin{array}{c}0.2167 \\
(0.45)\end{array}$ \\
\hline Tangibility & $\begin{array}{c}-1.3156^{*} \\
(-3.01)\end{array}$ & $\begin{array}{c}-1.5104^{* *} \\
(1.97)\end{array}$ & $\begin{array}{c}-2.2271 \text { * } \\
(-2.93)\end{array}$ & $\begin{array}{c}-1.7410 \text { * } \\
(3.89)\end{array}$ \\
\hline Liquidity & $\begin{array}{l}1.1551 \\
(1.54)\end{array}$ & $\begin{array}{c}3.1308^{* *} \\
(2.15)\end{array}$ & $\begin{array}{c}3.7468 \text { * } \\
(3.34)\end{array}$ & $\begin{array}{c}0.9349 \\
(1.28)\end{array}$ \\
\hline Operating revenue & $\begin{array}{c}0.02765 \\
(1.56)\end{array}$ & $\begin{array}{c}-0.1364^{* *} \\
(-2.20)\end{array}$ & $\begin{array}{c}-0.1853 \text { * } \\
(-2.97)\end{array}$ & $\begin{array}{c}0.0335^{* * *} \\
(1.91)\end{array}$ \\
\hline Revenue growth (3-year) & $\begin{array}{l}-0.0013 \\
(-0.02) \\
\end{array}$ & $\begin{array}{c}0.03421 \\
(0.56)\end{array}$ & $\begin{array}{c}0.03896 \\
(0.65)\end{array}$ & $\begin{array}{c}-0.0113 \\
(-0.20) \\
\end{array}$ \\
\hline Constant & $\begin{array}{c}-4.1381 \text { ** } \\
(-2.17)\end{array}$ & $\begin{array}{l}-1.596 \\
(-0.40)\end{array}$ & $\begin{array}{c}-0.14843 \\
(-0.08)\end{array}$ & $\begin{array}{c}-1.2106 \\
(-1.08)\end{array}$ \\
\hline F-test & & $\begin{array}{c}3.44 \\
(0.0023)\end{array}$ & $\begin{array}{c}6.90 \\
(0.0000)\end{array}$ & \\
\hline Hausman test & $\begin{array}{c}17.72 \\
(0.0000)\end{array}$ & & & $\begin{array}{c}38.67 \\
(0.0000)\end{array}$ \\
\hline Breusch-Pagan test & $\begin{array}{c}0.62 \\
(0.2150)\end{array}$ & & & $\begin{array}{c}2.88 \\
(0.0449)\end{array}$ \\
\hline
\end{tabular}

$*, * *$ and ${ }^{* * *}$ are measured for $1 \%, 5 \%$ and $10 \%$ level of significance.

\section{Discussion}

The relationship between capital structure and firm performance can be summarized in two different ways: leverage and firm performance, and long-term debt and firm performance. These themes are discussed in the following section.

In the Table 8 above, leverage is significantly associated with operating margin but has significant negative association with two measures of firm performance: return on assets and return on invested capital. In Table 9, other control variables have influenced profitability in positive and negative ways. Tangibility has affected operating margin, return on vested capital and return on equity negatively, suggesting that Australian firms are overinvesting on fixed assets. Revenue growth has also affected operating margin and return on assets significantly. Depreciation tax shield is observed to have affected operating margin negatively and liquidity has affected return on equity positively. The constant is significant in both operating margin and return on invested capital, suggesting a guaranteed minimum return from the presence of service sector firms in the economy. However, return on assets and return on equity, not assumed as constants, are not significant at any level of confidence.

In the table below, all relevant regression models are summarized to demonstrate the effect of long-term debt being used to finance total assets in order to improve firms' performance in the Australian services sectors. 
Table 8. Leverage and its effect of firm performance.

\begin{tabular}{|c|c|c|c|c|}
\hline \multirow[t]{2}{*}{ Variables } & \multicolumn{4}{|c|}{ Performance Measures Used } \\
\hline & $\begin{array}{l}\text { Operating } \\
\text { Margin }\end{array}$ & $\begin{array}{l}\text { Return on } \\
\text { Assets }\end{array}$ & $\begin{array}{c}\text { Return on } \\
\text { Invested Capital }\end{array}$ & $\begin{array}{l}\text { Return on } \\
\text { Equity }\end{array}$ \\
\hline & REM & REM & REM & FEM \\
\hline Leverage & $\begin{array}{l}0.2411^{* *} \\
(-2.23)\end{array}$ & $\begin{array}{l}-1.1143 * \\
(-3.75)\end{array}$ & $\begin{array}{l}-7.509 * * \\
(-2.42)\end{array}$ & $\begin{array}{l}3.7031 \\
(-1.41)\end{array}$ \\
\hline Depreciation tax shield & $\begin{array}{c}1265 \\
(-0.36)\end{array}$ & $\begin{array}{l}0.01242 \\
(-0.13)\end{array}$ & $\begin{array}{l}-2.4426^{* *} \\
(-2.45)\end{array}$ & $\begin{array}{c}-0.9583 \\
(-1.15)\end{array}$ \\
\hline Tangibility & $\begin{array}{c}-0.0584^{* * *} \\
(-1.80)\end{array}$ & $\begin{array}{c}-0.01436 \\
(-0.16)\end{array}$ & $\begin{array}{l}-3.152 * \\
(-3.41)\end{array}$ & $\begin{array}{l}-1.5104^{* *} \\
(-1.97)\end{array}$ \\
\hline Liquidity & $\begin{array}{l}0.0191 \\
(-0.32)\end{array}$ & $\begin{array}{l}0.2029 \\
(-1.24)\end{array}$ & $\begin{array}{l}0.09087 \\
(-0.05)\end{array}$ & $\begin{array}{l}3.1308^{* *} \\
(-2.15)\end{array}$ \\
\hline Operating revenue & $\begin{array}{l}0.0046 * \\
(-2.84)\end{array}$ & $\begin{array}{l}0.02992 * \\
(-6.61)\end{array}$ & $\begin{array}{l}0.2100 * \\
(-4.09)\end{array}$ & $\begin{array}{l}-0.1364 \text { ** } \\
(-2.20)\end{array}$ \\
\hline $\begin{array}{l}\text { Revenue growth } \\
\text { (3-year) }\end{array}$ & $\begin{array}{c}-0.0074^{* *} \\
(-2.45)\end{array}$ & $\begin{array}{l}0.0168^{* *} \\
(-2.06)\end{array}$ & $\begin{array}{l}0.0623 \\
(-0.78)\end{array}$ & $\begin{array}{c}0.03421 \\
-0.56\end{array}$ \\
\hline contant & $\begin{array}{c}0.5986 * \\
(3.92)\end{array}$ & $\begin{array}{c}0.321 \\
(-0.76)\end{array}$ & $\begin{array}{c}8.1662 * * * \\
(-1.83)\end{array}$ & $\begin{array}{l}-1.596 \\
(-0.40)\end{array}$ \\
\hline F-test & & & & $\begin{array}{c}3.44 \\
(-0.0023)\end{array}$ \\
\hline Hausman test & $\begin{array}{c}24.85 \\
(0.0000)\end{array}$ & $\begin{array}{c}26.13 \\
(-0.0002)\end{array}$ & $\begin{array}{c}35.01 \\
(0.000)\end{array}$ & \\
\hline Breusch-Pagan test & $\begin{array}{c}445.16 \\
(0.0000)\end{array}$ & $\begin{array}{c}544.07 \\
(0.0000)\end{array}$ & $\begin{array}{c}13.67 \\
(0.000)\end{array}$ & \\
\hline
\end{tabular}

$*, * *$ and ${ }^{* * *}$ are measured for $1 \%, 5 \%$ and $10 \%$ level of significance.

In the Table 9 above, long-term debt to finance assets is significantly associated (positively) with all measures of firm performance, except operating margin. Depreciation tax shield significantly influenced return on invested capital negatively while tangibility has negatively affected, at different levels of statistical significance, all measures of firm performance except return on assets. Liquidity has affected firm performance in all instances, natively in operating profit, and positively (at different levels of statistical significance) in improving return on assets and return on invested capital. Operating revenue positively influenced all measures of firm performance except return on assets. Finally, revenue growth for three years was a significantly influential negative factor in affecting operating margin but a positive factor in improving return on assets.

In light of the discussions above, we can say, 'capital structure matters.' It enhances the performance of the service sectors in Australia not only through improved operating margin and higher return on invested capital; it also increases shareholder value by improving return on equity and return on assets. As observed in our data analysis, we have used four different measures of firm performance. Three of these measures relate to balance sheets and the other one relates to profit and loss in the short-term. Leverage in all measures of performance was significant at the $1 \%$ level except when return on invested capital was used to measure firm performance. Even in the presence of other variables (used in the literature as explanatory variables) that showed significant influence in firm performance, leverage remains significant in shaping the performance of service sector firms in Australia. The positive and significant relationship between leverage and operating margin implies that the service sectors in Australia can greatly benefit by increasing the debt level in its capital structure. The negative and significant relationship with tangibility also makes economic sense and implies that tying funds in fixed assets can be detrimental to operating profits as the company will have lees funds available for generating revenues. 
Table 9. Long-term debt and its effect on firm performance.

\begin{tabular}{|c|c|c|c|c|}
\hline \multirow[t]{2}{*}{ Variables } & \multicolumn{4}{|c|}{ Performance Measures Used } \\
\hline & $\begin{array}{l}\text { Operating } \\
\text { Margin }\end{array}$ & $\begin{array}{l}\text { Return on } \\
\text { Assets }\end{array}$ & $\begin{array}{c}\text { Return on } \\
\text { Invested Capital }\end{array}$ & $\begin{array}{l}\text { Return on } \\
\text { Equity }\end{array}$ \\
\hline & REM & REM & REM & REM \\
\hline LTD_TA & $\begin{array}{l}-0.0295 \\
(-0.88)\end{array}$ & $\begin{array}{l}0.2475^{* *} \\
(-2.49)\end{array}$ & $\begin{array}{c}1.6844^{* * *} \\
(-1.83)\end{array}$ & $\begin{array}{l}1.2797^{* *} \\
(-2.45)\end{array}$ \\
\hline Depreciation tax shield & $\begin{array}{l}-0.0179 \\
(-0.51)\end{array}$ & $\begin{array}{l}-0.1288 \\
(-1.13)\end{array}$ & $\begin{array}{c}-2.2261^{* *} \\
(-2.23)\end{array}$ & $\begin{array}{l}0.2167 \\
(-0.45)\end{array}$ \\
\hline Tangibility & $\begin{array}{c}-0.0648^{* *} \\
(-1.97)\end{array}$ & $\begin{array}{c}0.081 \\
(-0.77)\end{array}$ & $\begin{array}{l}-3.0967 * \\
(-3.33)\end{array}$ & $\begin{array}{c}-1.7410 * \\
(-3.89)\end{array}$ \\
\hline Liquidity & $\begin{array}{c}-0.0893^{* * *} \\
(-1.78)\end{array}$ & $\begin{array}{l}0.9096 * \\
(-5.82)\end{array}$ & $\begin{array}{l}4.0090 * \\
(-2.86)\end{array}$ & $\begin{array}{l}0.9349 \\
(-1.28)\end{array}$ \\
\hline Operating revenue & $\begin{array}{l}0.0059 * \\
(-3.68)\end{array}$ & $\begin{array}{c}0.012 \\
(-1.39)\end{array}$ & $\begin{array}{l}0.1623 * \\
(-3.15)\end{array}$ & $\begin{array}{c}0.0335^{* * *} \\
(-1.91)\end{array}$ \\
\hline $\begin{array}{l}\text { Revenue growth } \\
\text { (3-year) }\end{array}$ & $\begin{array}{c}-0.0080 * \\
(-2.65)\end{array}$ & $\begin{array}{l}0.0193^{* *} \\
(-2.32)\end{array}$ & $\begin{array}{c}0.0803 \\
(-1.000)\end{array}$ & $\begin{array}{l}-0.0113 \\
(-0.20)\end{array}$ \\
\hline Constant & $\begin{array}{l}0.9457 * \\
(-12.37)\end{array}$ & $\begin{array}{l}-1.2744^{*} \\
(-4.82)\end{array}$ & $\begin{array}{c}-3.6585^{* * *} \\
(-1.70)\end{array}$ & $\begin{array}{l}-1.2106 \\
(-1.08)\end{array}$ \\
\hline Hausman test & $\begin{array}{c}3.800 \\
(-0.7033) \\
\end{array}$ & $\begin{array}{c}21.04 \\
(-0.0016) \\
\end{array}$ & $\begin{array}{c}16.76 \\
(-0.0102) \\
\end{array}$ & $\begin{array}{c}38.67 \\
(0.000) \\
\end{array}$ \\
\hline Breusch-Pagan test & $\begin{array}{c}480.54 \\
(0.0000)\end{array}$ & $\begin{array}{c}532.38 \\
(0.0000)\end{array}$ & $\begin{array}{l}1166.45 \\
(0.0000)\end{array}$ & $\begin{array}{c}2.88 \\
(-0.0449)\end{array}$ \\
\hline
\end{tabular}

Long-term debt to total assets does not play any role in operating margin as the service sectors can generate frequent cash flows and turnover rate is very high. As such, need for long-term debt is irrelevant. The economic impact is different for return on assets where our analysis shows that both leverage and long-term debt to total assets are positively significant in impacting return on assets under both REM and FEM. It further strengthens our earlier arguments that service sectors greatly benefit from increased debt level in its capital structure. Revenue growth for three years also shows promising impact on return on asset which also remain positively significant. When we tested our model for ROIC, we find that leverage is negatively significant whereas long-term debt to total asset remains positively significant. The negative relationship with leverage implies that firms face challenges in return on invested capital if too much of the funds are tied with short-term borrowing as they are payable quickly. In addition, just like in operating margin, tangibility remains negatively significant implying that firms are adversely affected by increased tangible assets holding. Finally, when analyzing the relationship with return on equity, just like ROA, we observe that both leverage and long-term debt to total assets remain positively significant. Unlike ROA, tangibility remains negatively significant with ROE. In conclusion, we can assert that in the case of service sector firms in Australia, a high level of leverage and a high level of long-term debt in capital structure is beneficial to increasing shareholders' wealth.

\section{Conclusions}

This paper has examined firm level characteristics and firm performance (or profitability) of service sector firms listed in the Australian Stock Exchange (ASX). Using a panel regression approach on data collected over an eleven-year period (2009-2019), the effect of capital structure and leverage was examined. Four measures of firm performance were used: return on assets, return on equity, operating margin ratio and return on capital employed. The analysis of data reveals a significant association between return on equity and leverage levels. Leverage affects firm performance at a statistically 
significant level in these service sector firms. For every dollar of increase in leverage, operating margin improves by 0.24 times, return on assets reduces by 1.11 times and return on invested capital reduces by 7.59 times (all statistically significant at the $1 \%$ and $5 \%$ level), suggesting that Australian services sector firms are not benefitting much from the use of debts to finance their operations. This finding is in sharp contrast to asymmetric information theory that suggests that lower debt levels hide firm performance (Myers 1984). In fact, they are overburdened with debts. When long-term debt is used to finance total assets, the picture changes dramatically. Return on assets, return on invested capital and return on equity changes by 0.24 times (significant at $5 \%$ level), return on capital employed increases by 1.68 times (significant at 10\% level) and return on equity improves by 1.27 times (significant at the $5 \%$ level), suggesting the positive value adding contributions of the use of long-term debt. The directional causality tests, as captured in the Granger causality test, indicated a positive unidirectional association between leverage and operating margin, bi-directional causality with return on assets (negative) and return on invested capital, with return on assets (negative) and a unidirectional (positive) causality between leverage and return on equity. The test also identified a bidirectional causality between long-term debt to total assets and operating margin, and a bidirectional relationship with return on assets, return on invested capital and return on equity. The presence of unidirectional and bidirectional causality between different types of debts to finance operations mean significant interdependencies and negative effects of debt on service sector firms in Australia.

The study has the inherent limitations of any research project. The sample size may be questioned for two reasons: the number of firms from the Australian service sector and the years included in the data. Due to unavailability of data, only three years of data are used. Inclusion of more years can be a possibility for the extension of the current research project. Interested researchers may consider a robust dataset, encompassing industries from all sectors of the Australian economy. The current study has examined a limited number of constructs to reflect on the profitability of Australian service sector listed firms. The influence of extra-organizational factors may contribute to the profitability of Australian service sector companies. Researchers willing to pursue the line of inquiry in this paper may include economic factors such as inflation, interest rate and GDP in future research. Finally, service sector heterogeneity may be partially responsible for poor reflection of profitability. So the inclusion of industry effects may be worthwhile before a conclusion can be reached about the industry sector effect on Australian service sector performance.

Author Contributions: R.A. developed the research idea and conducted review of literature. R.A. collected the data under the guidance and recommendation of R.B. and run the statistical analysis which is also suggested by R.B. R.B. provided the insights of the statistical results and analysis. Both authors have read and agreed to the published version of the manuscript.

Funding: This research received no external funding.

Conflicts of Interest: The authors declare no conflict of interest.

\section{References}

Abor, Joshua. 2007. Corporate governance and financing decisions of Ghanaian listed firms. Corporate Governance: The International Journal of Business in Society 7: 83-92. [CrossRef]

Ahmed Sheikh, Nadeem, and Zongjun Wang. 2011. Determinants of capital structure: An empirical study of firms in manufacturing industry of Pakistan. Managerial Finance 37: 117-33. [CrossRef]

Arifin, Agus Zainul. 2017. Interactions between capital structure and profitability: Evidence from Indonesia stock exchange. International Journal of Economic Perspectives 11: 117-21.

Australian Bureau of Statistics. 2019. Australian System of National Accounts, 2018-19 5204.0. Canberra: Australian Bureau of Statistics.

Australian Bureau of Statistics. 2020. Labour Force, Australia, Detailed, Quarterly, May 2020. (6291.0.55.003). Canberra: Australian Bureau of Statistics. 
Barth, James Richard, Gerard Caprio Jr., and Ross Levine. 2001. Banking Systems around the Globe: Do Regulation and Ownership Affect Performance and Stability? In Prudential Supervision: What Works and What Doesn't. Chicago: University of Chicago Press, pp. 31-96.

Baxter, Nevins D. 1967. Leverage, risk of ruin and the cost of capital. The Journal of Finance 22: 395-403.

Canarella, Giorgio, and Stephen Michael Miller. 2018. The determinants of growth in the U.S. information and communication technology (ICT) industry: A firm-level analysis. Economic Modelling 70: 259-71. [CrossRef]

Chadha, Saurabh, and Anil Kumar Sharma. 2015. Capital Structure and Firm Performance: Empirical Evidence from India. Vision 19: 295-302. [CrossRef]

Chakrabarti, Anindita, and Ahindra Chakrabarti. 2019. The capital structure puzzle-Evidence from Indian energy sector. International Journal of Energy Sector Management 13: 2-23. [CrossRef]

Choi, Serin, Seoki Lee, Kyuwan Choi, and Kyung-A Sun. 2018. Investment-cash flow sensitivities of restaurant firms: A moderating role of franchising. Tourism Economics 24: 560-75. [CrossRef]

Dalci, Ilhan. 2018. Impact of financial leverage on profitability of listed manufacturing firms in China. Pacific Accounting Review 30: 410-32. [CrossRef]

Dave, Ashvin, Ashwin Parwani, Ashish Joshi, and Tejas Dave. 2019. A study of capital structure and profitability of Indian steel sector companies. International Journal of Advanced Science and Technology 28: 866-73.

DeAngelo, Harry, and Ronald W. Masulis. 1980. Optimal capital structure under corporate and personal taxation. Journal of Financial Economics 8: 3-29. [CrossRef]

Donaldson, Gordon. 1984. Managing Corporate Wealth. New York: Praeger.

El-Sayed Ebaid, Ibrahim. 2009. The impact of capital-structure choice on firm performance: Empirical evidence from Egypt. The Journal of Risk Finance 10: 477-87. [CrossRef]

Fama, Eugene Frank, and Kenneth Richard French. 1998. Value versus growth: The international evidence. Journal of Finance 53: 1975-99. [CrossRef]

Fitim, Deari, Matsuk Zoriana, and Lakshina Valeriya. 2019. Leverage and Macroeconomic Determinants: Evidence from Ukraine. Studies in Business and Economics 14: 5-19. [CrossRef]

Gharaibeh, Omar Krishna, and Marie Hal Bani Khaled. 2020. Determinants of profitability in Jordanian services companies. Investment Management and Financial Innovations 17: 277-90. [CrossRef]

Ghasemi, Maziar, Nazrul Hisyam Ab Razak, and Komeli Dehghani. 2018. Determinants of debt structure in ACE Market Bursa Malaysia: A panel data analysis. Journal of Social Sciences Research 2018: 390-95. [CrossRef]

Ghosh, Chinmoy, Raja Nag, and C. F. Sirmans. 2000. The pricing of seasoned equity offerings: Evidence from REITs. Real Estate Economics 28: 363-84. [CrossRef]

Gleason, Kimberley Clark, Linette Knowles Mathur, and Ike Mathur. 2000. The interrelationship between culture, capital structure, and performance: Evidence from European retailers. Journal of Business Research 50: 185-91. [CrossRef]

Goddard, John, Manouche Tavakoli, and John Oliver Wilson. 2005. Determinants of profitability in European manufacturing and services: Evidence from a dynamic panel model. Applied Financial Economics 15: 1269-82. [CrossRef]

Grossman, Sanford John, and Oliver David Hart. 1982. Corporate financial structure and managerial incentives. In The Economics of Information and Uncertainty. Chicago: University of Chicago Press, pp. 107-40.

Hadlock, Charles Jones, and Christopher M. James. 2002. Do banks provide financial slack? The Journal of Finance 57: 1383-419. [CrossRef]

Helmy, Muhammad Harith Zulqarnain Bin Noor, Goh Chin Fei, Tan Owee Kowang, Ong Choon Hee, Tan Seng Teck, Lim Kim Yew, and Wong Chee Hoo. 2020. Capital structure, internal governance mechanisms and firm performance. International Journal of Psychosocial Rehabilitation 24: 7313-21. [CrossRef]

Hussein, Mohammed Jalal, Alrabba Hussein, Muhannad Akram Ahmad, and Mashhoor Hamadneh. 2019. Capital structure and firm performance: Evidence from Jordanian listed companies. International Journal of Scientific and Technology Research 8: 364-75.

Jensen, Michael Clark. 1986. Agency cost of free cash flow, corporate finance, and takeovers. Corporate Finance, and Takeovers. American Economic Review 76: 323-29.

Jensen, Michael Clark, and William H. Meckling. 1976. Theory of the firm: Managerial behavior, agency costs and ownership structure. Journal of Financial Economics 3: 305-60. [CrossRef]

Khan, Tasneem, Mohd Shamim, and Jatin Goyal. 2018. Panel data analysis of profitability determinants: Evidence from Indian telecom companies. Theoretical Economics Letters 8: 3581-93. [CrossRef] 
Köksal, Bülent, and Cüneyt Orman. 2015. Determinants of capital structure: Evidence from a major developing economy. Small Business Economics 44: 255-82. [CrossRef]

Kraus, Alan, and Robert H. Litzenberger. 1973. A state-preference model of optimal financial leverage. The Journal of Finance 28: 911-22. [CrossRef]

Levin, Andrew, Chien-Fu Lin, and Chia-Shang James Chu. 2002. Unit root tests in panel data: Asymptotic and finite-sample properties. Journal of Econometrics 108: 1-24. [CrossRef]

Li, Hui, and Petros Stathis. 2017. Determinants of Capital Structure in Australia: An Analysis of Important Factors. Managerial Finance 43: 881-97. [CrossRef]

M'ng, Jacinta Chan Phooi, Mahfuzur Rahman, and Selvam Sannacy. 2017. The determinants of capital structure: Evidence from public listed companies in Malaysia, Singapore and Thailand. Cogent Economics and Finance 5: 1418609. [CrossRef]

Macan Bhaird, Ciarán, and Brian Lucey. 2010. Determinants of capital structure in Irish SMEs. Small Business Economics 35: 357-75. [CrossRef]

Mayuri, Tulsi, and Lingesiya Kengatharan. 2019. Determinants of Capital Structure: Evidence from Listed Manufacturing Companies in Sri Lanka. SCMS Journal of Indian Management 16: 43-56.

Modigliani, Franco, and Merton H. Miller. 1958. The cost of capital, corporation finance and the theory of investment. The American Economic Review 48: 261-97.

Modigliani, Franco, and Merton H. Miller. 1963. Corporate income taxes and the cost of capital: A correction. The American Economic Review 53: 433-43.

Musah, Mohammed, and Yusheng Kong. 2019. The relationship between capital structure and the financial performance of non-financial firms listed on the Ghana Stock Exchange (GSE). International Journal of Research in Social Sciences 9: 92-123.

Myers, Stewart Charles. 1984. The capital structure puzzle. The Journal of Finance 39: 574-92. [CrossRef]

Myers, Stewart C., and Nicholas Samual Majluf. 1984. Corporate financing and investment decisions when firms have information that investors do not have. Journal of Financial Economics 13: 187-221. [CrossRef]

Negasa, Tran. 2016. The Effect of Capital Structure on Firms' Profitability (Evidenced from Ethiopian). Preprints, 2016070013. [CrossRef]

Nunes, Paulo J. Maçãs, Zélia M. Serrasqueiro, and Tiago N. Sequeira. 2009. Profitability in Portuguese service industries: A panel data approach. The Service Industries Journal 29: 693-707. [CrossRef]

Park, Kwangmin, and SooCheong Jang. 2018. Is franchising an additional financing source for franchisors? A Blinder-Oaxaca decomposition analysis. Tourism Economics 24: 541-59. [CrossRef]

Pettit, Richardson, and Ronald F. Singer. 1985. Small business finance: A research agenda. Financial Management 14: 47-60. [CrossRef]

Qiu, Mei, and Bo La. 2010. Firm characteristics as determinants of capital structures in Australia. International journal of the Economics of Business 17: 277-87. [CrossRef]

Rashid, Kashif, and Sardar Islam. 2009. Capital structure and firm performance in the developed financial market. Corporate Ownership and Control 7: 189-201. [CrossRef]

Roden, Dianne M., and Wilbur Grand Lewellen. 1995. Corporate Capital Structure Decisions: Evidence from Leveraged Buyouts. Financial Management 24: 76-87. [CrossRef]

Ross, Stephen Allen. 1977. The determination of financial structure: The incentive-signalling approach. The Bell Journal of Economics 8: 23-40. [CrossRef]

Salim, Mahfuzah, and Raj Yadav. 2012. Capital Structure and Firm Performance: Evidence from Malaysian Listed Companies. Procedia-Social and Behavioral Sciences 65: 156-66. [CrossRef]

Sardo, Filipe, Zélia Serrasqueiro, and Elisabete GS Félix. 2020. Does Venture Capital affect capital structure rebalancing? The case of small knowledge-intensive service firms. Structural Change and Economic Dynamics 53: 170-79. [CrossRef]

Sermpinis, Georgios, Serafeim Tsoukas, and Ping Zhang. 2019. What influences a bank's decision to go public? International Journal of Finance and Economics 24: 1464-85. [CrossRef]

Shalini, Ramaswamy, and Mahua Biswas. 2019. Capital structure determinants of SandP BSE 500: A panel data research. International Journal of Recent Technology and Engineering 8: 377-80. [CrossRef]

Sivalingam, Logavathani, and Lingesiya Kengatharan. 2018. Capital Structure and Financial Performance: A Study on Commercial Banks in Sri Lanka. Asian Economic and Financial Review 8: 586-98. [CrossRef] 
Stulz, René. 1990. Managerial discretion and optimal financing policies. Journal of Financial Economics 26: 3-27. [CrossRef]

Suntraruk, Phassawan, and Xiaoxing Liu. 2017. The impacts of institutional characteristics on capital structure: Evidence from listed commercial banks in China. Afro-Asian Journal of Finance and Accounting 7: 337-50. [CrossRef]

Szemán, Judith. 2017. Relevance of Capital Structure Theories in the Service Sector. Theory, Methodology, Practice 13: 53-64. [CrossRef]

Taub, Allan Jay. 1975. Determinants of the firm's capital structure. The Review of Economics and Statistics 57: 410-16. [CrossRef]

Weill, Laurent. 2008. Leverage and corporate performance: Does institutional environment matter? Small Business Economics 30: 251-65. [CrossRef]

Yazdanfar, Darush. 2012. The Impact of Financing Pattern on Firm Growth: Evidence from Swedish Micro Firms. International Business Research 5: 16. [CrossRef]

Yazdanfar, Darush, and Peter Öhman. 2015. Debt financing and firm performance: An empirical study based on Swedish data. The Journal of Risk Finance 16: 102-18. [CrossRef]

(C) 2020 by the authors. Licensee MDPI, Basel, Switzerland. This article is an open access article distributed under the terms and conditions of the Creative Commons Attribution (CC BY) license (http://creativecommons.org/licenses/by/4.0/). 